Article

\title{
Sustainable Development of the Energy Sector in a Country Deficient in Mineral Resources: The Case of the Republic of Moldova
}

\author{
Ecaterina Resniova *(D) and Tatiana Ponomarenko
}

Citation: Resniova, E.; Ponomarenko, T. Sustainable Development of the Energy Sector in a Country Deficient in Mineral Resources: The Case of the Republic of Moldova. Sustainability 2021, 13, 3261. https://doi.org/ $10.3390 /$ su13063261

Academic Editor: María Teresa García Álvarez

Received: 12 February 2021

Accepted: 12 March 2021

Published: 16 March 2021

Publisher's Note: MDPI stays neutral with regard to jurisdictional claims in published maps and institutional affiliations.

Copyright: (C) 2021 by the authors Licensee MDPI, Basel, Switzerland. This article is an open access article distributed under the terms and conditions of the Creative Commons Attribution (CC BY) license (https:// creativecommons.org/licenses/by/ $4.0 /)$.
Department of Economics, Organization and Management, The Faculty of Economics, Saint-Petersburg Mining University, 2, 21st Line, 199106 St Petersburg, Russia; Ponomarenko_TV@pers.spmi.ru

* Correspondence: reshniovakate@gmail.com; Tel.: +7-952-236-54-18

Abstract: The energy sector is an essential element in an economy's infrastructure, so a deficit of national mineral resources makes the energy sector dependent on imports of raw materials, which in turn can negatively affect a country's energy security. The sustainable development of the energy sector for countries with transitioning economies should be based on the energy trilemma. Four principles are proposed: diversification of energy resources and energy generation sources, ensuring energy efficiency, ensuring energy affordability, and green energy production. Based on a comparative analysis of the economic and energy indicators (for the years 2014 to 2019) of European countries that are not members of the European Union, the situation in the energy sector of the Republic of Moldova is classified as critical and its fundamental issues are identified (107th place in the World Energy Trilemma Index). The main objectives of the study are: (1) To analyze energy and economic efficiency as well as the conditions for and problems of the functioning of the energy sector in countries with transition economies (using non-European Union countries as an example); (2) To present a substantiation of the directions for development of the energy sector in countries with transition economies that lack energy resources (using the Republic of Moldova as an example), taking into account the identified factors and principles of sustainable development; (3) To develop an economic and mathematical model for assessing the directions for the development of the energy sector in countries with transition economies using multiple-criteria decision analysis (MCDA). Decision-making methods can be used to select strategic development alternatives, particularly in the energy sector. MCDA has several advantages and uses in the following situations: comparing several alternatives; identifying the most preferable and unacceptable alternatives; comparing alternatives based on several (sometimes conflicting) criteria; looking for a compromise in a situation where different stakeholders have conflicting goals or values. A methodology including a system of 7 indicators and an economic and mathematical model for assessing development paths for the energy sector in countries with transition economies were developed that are based on multiplecriteria decision analysis. An algorithm and a computer program were developed to carry out MCDA and select the best development path for the energy sector of the Republic of Moldova. The article presents a rationale for choosing the best option regarding the development of the energy sector of the Republic of Moldova, which is a country with a deficit of its own energy resources.

Keywords: energy trilemma; the energy sector; multiple-criteria decision analysis (MCDA); renewable energy sources; shortage of energy sources; sustainable development; World Energy Trilemma Index

\section{Introduction}

Since the middle of the 1980s, research in the field of sustainable development (SD) has become intensive in terms of both methodology and the variety of research objects [1-7]. There is a well-known interpretation of SD that was given by the UN's World Commission on Environment and Development in 1987: "Humanity has the ability to make development 
sustainable to ensure that it meets the needs of the present without compromising the ability of future generations to meet their own needs. The concept of sustainable development does imply limits-not absolute limits but limitations imposed by the present state of technology and social organization on environmental resources and by the ability of the biosphere to absorb the effects of human activities... sustainable development requires meeting the basic needs of all and extending to all the opportunity to fulfil their aspirations for a better life" [8]. Such an interpretation focuses on actions and the management of changes that are aimed at ensuring SD.

Different concepts explain and combine the three sides of SD in various ways $[9,10]$. These three sides include: economic sustainability, which is the development of production, natural, human, and social capital to improve economic performance; environmental sustainability, which means the conservation of ecosystems and the rational use of nonrenewable natural resources for sustainable production at the current moment and for future generations; and social sustainability, which means that the basic needs of all population groups should be met, which is directly linked with environmental and economic sustainability.

Research in the field of SD has been carried out in application to various sectors of the economy that are characterized by high levels of anthropogenic impact, environmental exploitation, and social significance [11,12]. The energy sector is an essential element of a country's infrastructure, is characterized by a high level of resource intensity and the use of mineral resources, and has a significant impact on the environment. The energy sector brings together companies and industries that are involved in the production and sale of energy. Energy generation has several specific features, such as simultaneous energy production and consumption, continuous production, the complexity of energy generating equipment and the specific conditions in which it is operated, interchangeability of energy generators, and a low level of electricity generation efficiency. To satisfy a population's needs, it is essential to ensure the economic development and sustainable functioning of the energy sector $[13,14]$. Therefore, in continuation of the SD concept, the World Energy Council has developed the energy trilemma concept [15], which means that energy should be green, safe, and available to everybody.

The concept includes the following ideas and approaches [10,15]:

(1) energy security, which means the efficient management of primary energy supply from domestic and foreign sources, the reliability of the energy infrastructure, and energy suppliers' ability to meet current and future demand;

(2) affordability and access, which means that all population groups have access to energy;

(3) environmental sustainability, which means the development of energy supplies from renewable and other low-carbon sources.

To perform a comprehensive assessment of energy sustainability in the context of sustainable development on a global scale, an energy sustainability index (the World Energy Trilemma Index) was developed [10]. It is connected with the energy trilemma concept and evaluates countries' performance across three sustainability dimensions in terms of their importance: energy security (30\%), energy equity (30\%), environmental sustainability $(30 \%)$, and local (national) circumstances $(10 \%)$. The index covers data from 133 countries, 92 of which are members of the World Energy Council. The values are divided into categories (from AAA to DDD), with the maximum value of AAA characterizing the country as one having a stable economy and excellent energy policy. This index is a tool that can be used in measuring how developed the energy sector of a country is, making a conclusion about the effectiveness of energy policy to ensure balanced energy management, analyzing competing priorities and development directions, and transferring experience from the leaders in the fields of energy policy, energy development, and green energy.

Sustainable development of the energy sector at the national level is primarily associated with ensuring the country's energy security, which is connected with optimizing the territorial structure of primary energy production and consumption, the rational use 
of energy resources, energy saving, and energy efficiency, the use of renewable energy sources, and the search for new ways to autonomously meet the energy needs of industrial facilities and population.

The aim of the study is to present a substantiation of the directions for sustainable development of the energy sector in countries with transition economies that are deficient in energy resources using a developed methodology that takes into account the requirements of energy security, energy equity, and environmental sustainability.

The main objectives of the study:

(1) To analyze energy and economic efficiency as well as the conditions for and problems of the functioning of the energy sector in countries with transition economies (using non-European Union countries as an example);

(2) To present a substantiation of the directions for development of the energy sector in countries with transition economies that lack energy resources (using the Republic of Moldova as an example) taking into account the identified factors and principles of sustainable development;

(3) To develop an economic and mathematical model for assessing the directions for the development of the energy sector in countries with transition economies using multiple-criteria decision analysis (MCDA).

The structure of this article is as follows: the next section provides an overview of research papers, while the «Methodology: MCDA and Economic and Mathematical Model» and the «Results» are described in the next two sections. The main results of the implementation of the selected development alternative are presented in Section 5. In the last section, an assessment of the solution of the main key research questions was provided; the main difficulties in implementing this technique and possible improvements were highlighted. Appendix A provides a comparative description of economic and energy indicators for countries with economies in transition, while Abbreviation part provides a table of nomenclature and acronyms.

\section{Literature Review}

Research on the sustainable development of the energy sector covers a wide range of issues, including the interpretation and measurement of sustainable energy development [4-6], the study of the sustainability of energy systems in developed and in countries with transition economies [16-20], the development of the concept of energy security [21-26], diversification of energy generation sources [1], the efficiency of using renewable energy sources [27-32], innovative development of the energy sector [33-35], energy management and energy efficiency management [36,37], and other issues in this sphere.

D.L. Green [4] defines energy sustainability as a guarantee that future generations will have energy resources that will enable them to achieve the same level of well-being as the one that the present generation has. This understanding of energy sustainability is fundamental for countries that have national energy sources and fuel reserves. For countries that are deficient in fossil fuels and energy resources, the sustainability of the energy sector can be ensured through well-developed strategic programs and operational efficiency on an innovative basis.

The energy trilemma concept is considered to be the foundation for the sustainable development of the energy sector $[15,38,39]$. This concept is of particular importance for countries with economies in transition that are characterized by a shortage of local fuel and energy resources. This factor has a direct impact on the economy, making it unstable and less efficient, which hampers the development of the energy sector. The issues of assessing national energy sustainability have not yet been resolved. The well-known energy sustainability index [10] is sometimes criticized. For example, the authors of [40] claim that this index cannot be used as a robust tool in energy policy management and the methodology should be improved since the end indicator of Cronbach's Alpha value (0.694) stands at the very margin of reliability $(0.600)$. 
The best possible balance between the elements of the energy trilemma can be ensured by applying strategic planning and management procedures to the energy sector, which is of specific importance in countries with transition economies.

Strategic planning and management procedures in the energy sector cover a wide range of issues. It should also be noted that the development of alternatives for the strategic development of this sector is risky as it can be affected by changes in technological, environmental, socio-economic, and political conditions [41]. The authors of [42] present a classification and a comparative analysis of methods for modeling the uncertainty of the decision-making process. As there is great uncertainty, the development of guidelines for the energy sector should take into account the country's strategic goals in this sector and be based on statistics and statistical forecasting. Best practices in the strategic modeling of electric power systems are summarized by A.M. Foley et al. [43], who discuss modeling methods and the key patented models of electric power systems used in the USA and Europe.

Researchers from different countries have widely studied the problems of the development of the energy sector. In particular, Moldovan experts carried out a comprehensive study of sustainable development issues in the country's energy sector. Elena Bicova, Energy Sector Lead at the Academy of Sciences of Moldova, studied in detail the reasons why the country's energy sector is in critical condition. The author notes that to ensure that the country's energy security is not endangered, it is necessary to solve the issue of energy resource shortage, make energy available to all groups of consumers, and create an energy cushion that will be used against power failures [24]. This comprehensive approach answers the purpose of ensuring energy security in the Republic of Moldova. D. Ofitserov-Belsky associates the main energy security problems of the Republic of Moldova with the country's internal problems, lack of interest on part of investors, and transmission problems associated with political issues [44]. The issue of integrating the energy sector of Moldova with the energy sectors of the European Union and CIS countries (Commonwealth of Independent States) started to be discussed back in the early 2000s. Academician V. Postolati argued that energy system integration and a common market for electricity are useful for the European Union and CIS countries. This is explained by the fact that each country needs to have a reliable power supply system while also making use of the well-known advantages of integrated systems without compromising the development of its own energy sector. Many years of partnerships between East and West in the energy sector prove that it is possible to do $[45,46]$. Also, sustainable development issues faced by the energy sector of Moldova were studied by I. Comendant [47], who analyzed various development scenarios in his works.

The above mentioned works do not describe methodologies for choosing alternatives for the development of the energy sector in countries with economies in transition that are deficient in energy resources. The study discussed here aims to fill this gap in research.

The following methods are used to shape strategies for the development of the energy industry at the national level: industry, scientific, technology, and macroeconomic forecasting, input-output analysis, cost-benefit analysis, as well as the development of coherent government strategies, policies, programs, and plans. These methods require high-quality strategic planning and forecasting at the national level, as well as a well-developed methodology. For example, one of the areas where input-output models are used is the assessment of the multiplier effects caused by the development of different branches of economic activity and the implementation of large-scale investment projects. The method is effective and useful, but its main problem lies in being complex and time-consuming as it relies on huge amounts of information and requires the use of strategic planning tools [48].

Today's academic papers and studies conducted by authoritative international organizations [49] propose statistical analysis methods and semantic modeling methods for systems analysis [50,51]. Statistical analysis methods require a substantial volume of structured information; semantic modeling methods require the development of digital, information, and intellectual technologies. 
Among the many methods for choosing strategic decisions in the development of the energy sector that are proposed in literature, the MCDA method has not yet been considered in substantiating the development paths of the energy sectors in countries with energy resource shortages.

The article proves that it is possible to use the MCDA method when choosing a sustainable development path for the energy sector in a country with a deficit of mineral resources. The academic novelty of the study lies in selecting and substantiating indicators for comparing energy sector development paths; they correspond to the concept of the energy trilemma proposed by the World Energy Council, are based on the proposed principles of sustainable development for the energy sector (Discussion), and take into account both the sustainable development factors for a specific country and an assessment of the state of the energy system. In the countries under consideration (Appendix A), the issues of sustainable development of the energy sector have remained unresolved for several decades. The presented methodology provides tools for boosting and improving the development of the energy system.

\section{Methodology: MCDA and Economic and Mathematical Model}

Decision-making methods can be used to select strategic development alternatives, in particular in the energy sector. MCDA has several advantages and use in the following situations: comparing several alternatives; identifying the most preferable and unacceptable alternatives; comparing alternatives based on several (sometimes conflicting) criteria; looking for a compromise in a situation where different stakeholders have conflicting goals or values [48].

MCDA is used as a tool for making decisions concerning the development of the energy sector due to the complexity of socio-economic systems and the multidimensionality of sustainable development goals [52,53]. In the energy sector, MCDA is used when making decisions on upgrading facilities and choosing options for building power stations and facilities operating on renewable energy sources, i.e., when making strategic steps at different levels. The purpose of MCDA is to provide methodological and instrumental support for choosing the best solution based on criteria specified by the stakeholders. MCDA methods form a system for analyzing multiple alternatives based on several criteria in order to overcome the limitations of unstructured decisions made by an individual or a group.

There are two approaches to conducting MCDA: the qualitative one and the quantitative one. In qualitative MCDA, decisions are made in the course of deliberative discussions covering multiple criteria and indicators. The qualitative approach can consider alternative solutions, but the decision-making process is not formalized, the influence of criteria and indicators on the object being analyzed remains unclear, the process is not transparent, and it is unlikely to be reproducible. The quantitative approach makes it possible to develop a formal decision-making method that is based on ranking alternatives using a preliminary assessment of different indicators through assigning weighting factors to them and taking their values into account. The quantitative approach ensures that the decision-making process is transparent, i.e., it is not influenced by the complexity of the situation, it is clear to the stakeholders, and it is coordinated. The disadvantages of the quantitative approach include a fixed number of criteria and their values and the need to collect a representative body of data and evidence supporting each of the alternatives [48].

To choose a strategic development path for the energy sector, relying on economic performance is not sufficient since environmental and social indicators should also be taken into account, including growth in the sustainable development indicators of the sector. To factor in economic, environmental, and social indicators as required by the Energy Trilemma, a methodology was developed using the quantitative approach applied in MCDA to choose the best development path for the energy sector and assess the consequences of this choice. 
The steps in the MCDA methodology are reviewed in detail in the section «Results» using the example of the Republic of Moldova and are presented in the form of a flow chart in Figure 1.

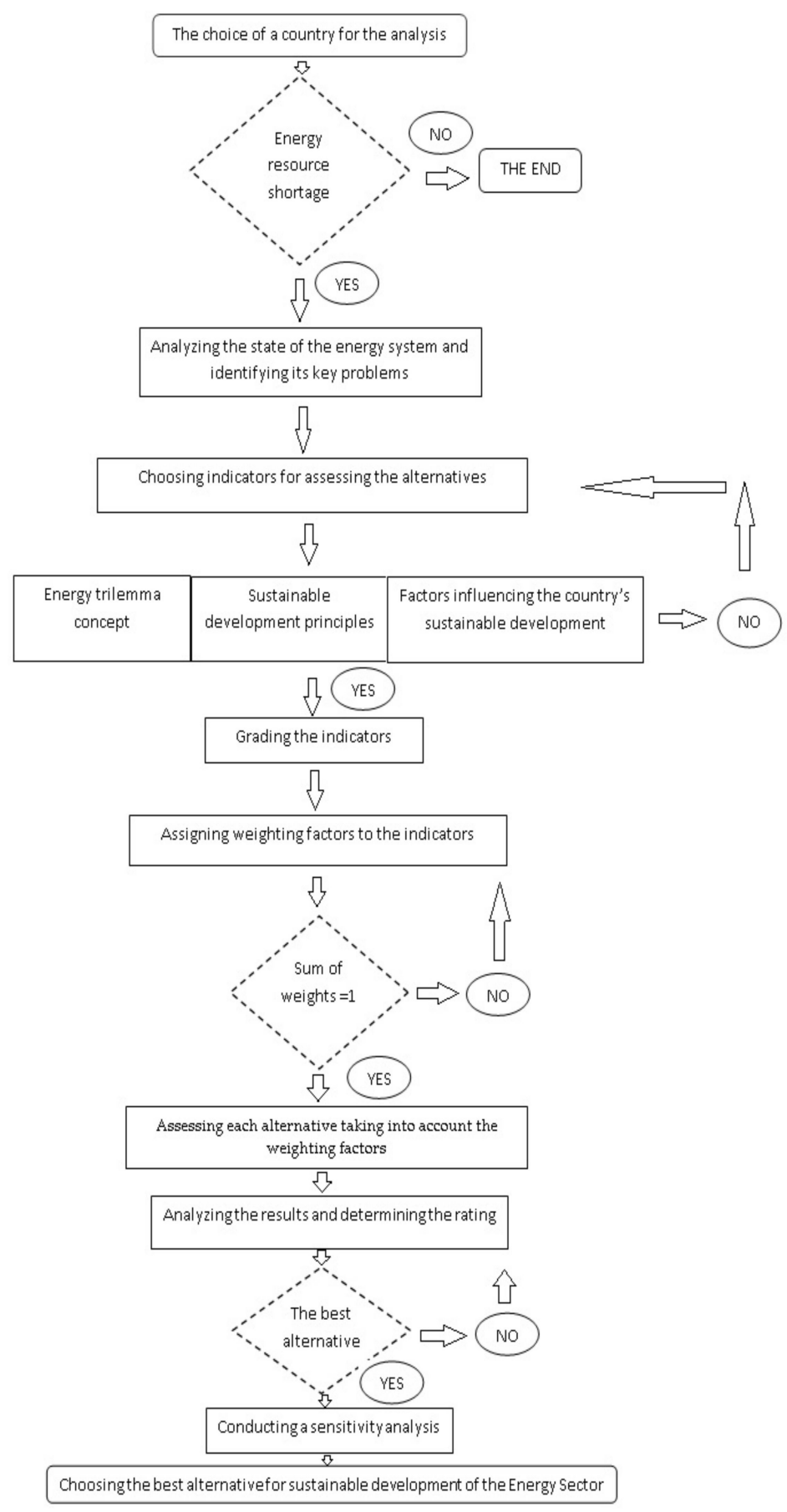

Figure 1. The main steps in the multiple-criteria decision analysis (MCDA) methodology. Source: Developed by the authors.

The aim of assessing different alternatives consists in selecting a development path for the energy sector reviewed country that will contribute to its sustainable development based on a set of principles (presented in «Discussion») and taking into account the factors of sustainable development, based on fundamental problems in the energy sector of the country in question. Sustainable development factors were identified based on the issues that led to the crisis in the energy sector of the Republic of Moldova, including 
economic (the need for investments and the lack of local energy sources accompanied by a high potential for green energy production), social (price regulation and requirements concerning energy security), and environmental ones (environmental sustainability), as well as government regulation (modernization of the energy system and the need for international interactions).

Table 1 shows the process of choosing indicators based on sustainable development factors for assessing the alternatives that were identified for the energy sector of the Republic of Moldova in the course of the study and meet the requirements of the energy trilemma concept.

Table 1. The sustainable development of the energy sector of the Republic of Moldova: factors and indicators.

\begin{tabular}{|c|c|c|}
\hline Factor & & Indicator \\
\hline 1. Need for investment to ensure development & $\rightarrow$ & Current investment value for a 20 -year period \\
\hline 2. Price regulation & $\rightarrow$ & Normalized price for a 20-year period \\
\hline 3. Energy security requirements & $\rightarrow$ & Energy security level \\
\hline $\begin{array}{l}\text { 4. Lack of local energy resources accompanied by } \\
\text { green energy production potential }\end{array}$ & $\rightarrow$ & Level of competition \\
\hline 5. Power equipment and network health & $\rightarrow$ & $\begin{array}{l}\text { An opportunity for East-West (and West-East) } \\
\text { power transmission }\end{array}$ \\
\hline 6. Environmental sustainability & $\rightarrow$ & Environmental impact \\
\hline 7. Government regulation of cross-border interactions & $\rightarrow$ & Operational issues \\
\hline
\end{tabular}

Source: Developed by the authors.

By analyzing the current situation and issues in the energy sector of the Republic of Moldova and the factors that were identified, the following indicators were selected to analyze the alternatives (Table 1$)[48,54]$ :

(1) Current investment value for a 20 -year period using a depreciation rate of $9 \%$, (USD $\mathrm{mln})$.

(2) Normalized price for a 20-year period, (cent/ $\mathrm{kWh}$ ).

(3) Energy security. This indicator was assessed using Simpson's Diversity Index that reflects the variety of energy sources and power generation methods. These sources include both domestic energy generation and energy provided by other producers (Ukraine, Transnistria, and Romania). The closer the value of the index to 1, the greater the number of electricity generation options.

(4) Level of competition. This indicator was assessed using the number of interconnections for each alternative. This index is equal to 0 for the alternatives within the self-sufficiency scenario, 1 for the alternatives within the synchronous interconnection scenario (with the exception of S-3, which implies two sources: Romania and the Moldavskaya GRES (Moldavian State District Power Plant)), and 3 for the asynchronous interconnection scenario (Romania, Ukraine, and the Moldavskaya GRES).

(5) An opportunity for East-West (and West-East) power transmission, (MWt). All the alternatives within the asynchronous scenario imply energy transmission at a maximum load of $870 \mathrm{MW}$ (the capacity required in 2033 if no new energy facilities are built). The two suppliers in the East are the Moldavskaya GRES and Ukraine. Of the alternatives within the synchronous scenario, S-3 includes only the Moldavskaya GRES. In the self-sufficiency alternatives, the transmission capacity is limited to 220 MW.

(6) Environmental impact (million tons) was calculated based on greenhouse gas emissions for each scenario ( $\mathrm{t} \mathrm{CO}$ over 20 years). It is $\mathrm{CO}_{2}$ that is one of the main air pollutants in the Republic of Moldova. The levels of methane and nitrogen oxide do not exceed $1 \%$ in $\mathrm{CO}_{2}$ equivalent [55].

(7) Operational issues include the number of existing power transmission lines that will need to be disconnected when implementing some alternative. 
At the step titled "grading the indicators», it is important to decide which indicators need to be minimized and which ones need to be maximized. In Moldova's case, the indicators to be maximized include the level of energy security, the level of competition, and an opportunity for East-West (and West-East) power transmission. The indicators to be minimized are current investment value for a 20-year period, the normalized price for a 20year period, environmental impact, and operational issues. A 100-point grading scale was used in the following way: for an indicator to be minimized, 0 points were considered to be the highest value and 100 points were considered to be the lowest value. The opposite was done for an indicator to be maximized. Intermediate values of the indicators (Inter.value) were calculated using the following Equations (1) and (2):

$$
\begin{aligned}
& \text { Inter.value }=\frac{\text { maxval. }- \text { actual val. }}{\text { maxval. }- \text { min val. }} \\
& \text { Inter.value }=\frac{\text { actual val. }- \text { min val. }}{\text { maxval. }- \text { min val. }}
\end{aligned}
$$

where max val.- -is the highest value of the indicator; actual val.- is the actual value of the indicator for a particular option; min. val.- -is the lowest value of the indicator.

To assign weighting factors to the indicators, the expert evaluation method was used in the study being discussed. In this method, the choice of weighting factors depends on their importance and priority ranking. The weighting factors range from 0 to 1 , with their sum being equal to 1 .

The final step (conducting a sensitivity analysis) makes it possible to find out to what extent the chosen alternative depends on changes in particular indicators.

The computer program was developed which goes through the following steps: scoring the indicators for each alternative; assigning weighting factors to the indicators; assessing the alternatives with the weighting factors taken into account; ranking the alternatives and choosing the best alternative; sensitivity analysis. The software that was developed has been registered in the Russian Federation with the Federal Service for Intellectual Property [56] and has a Russian interface.

\section{Results}

The choice of the energy sector of the Republic of Moldova as the object of research was made based on analyzing and comparing the energy sectors of European countries with transition economies deficient in energy resources. They share characteristics such as low levels of productive forces and social infrastructure and high levels of unemployment and population migration. According to the World Bank classification, countries with transition economies include some countries in Central and Eastern Europe whose income per capita is above average (\$2996 to \$9385) and below average (\$766 to \$2996). The Republic of Moldova belongs to the group of countries with below average income per capita [57,58]. In Europe, countries with transition economies include Albania, North Macedonia, Bosnia and Herzegovina, Serbia, Montenegro, and the Republic of Moldova. These countries developed as planned economies, and are currently not members of the EU. Table A1 presents data on the economic and energy indicators of the countries for years 2014 to 2019.

The countries are comparable in terms of population, area, and almost all energy indicators. Historically, most of these countries developed their energy infrastructure with the help of the USSR, with the majority of their energy facilities functioning since the Soviet times. The transition from a planned to a market economy was difficult for the development of the energy sector in these countries. They predominantly rely on fossil fuels. Nuclear power and alternative energy sources are hardly used. However, the potential of renewable energy sources is quite high.

In terms of the World Energy Trilemma Index, the countries under consideration are in the middle of the list of 128 countries, with the exception of the Republic of Moldova (№ 107). It should be noted that energy security (the first letter of each grade) in Bosnia and Herzegovina and Serbia is better (B) than in Albania and the Republic of Moldova 
(D). In terms of energy equity (the second letter), all countries demonstrate a good level (B) except for the Republic of Moldova (C). As for environmental sustainability (the third letter), Albania ranks highest (A), with the Republic of Moldova ranking lowest (D).

In Bosnia and Herzegovina, Serbia, and Montenegro, national electricity production exceeds national consumption, which indicates a balanced energy sector. All of the countries discussed except Bosnia and Herzegovina have electricity imports exceeding exports. The only country that does not export electricity is the Republic of Moldova.

In European countries with transition economies, household electricity prices per 1 $\mathrm{kWh}$ are approximately the same and quite low compared to the EU countries. To put this into perspective, the household electricity price is 0.3 euros in Denmark (as of 2019) and 0.29 euros in Germany and Belgium (as of 2019) [59]. The main factor that makes electricity prices high in the EU countries is a significant share of taxes in the cost, in particular the environmental tax. However, despite the fact that energy is quite cheap in European developing countries, it is not easily affordable, which is influenced by economic and technical factors. Compared to developed European countries (one average salary can buy 31,307 kWh in Liechtenstein, 19,689 kWh in Norway, and 13,031 kWh in France), energy is several times less affordable in developing countries. In this respect, the Republic of Moldova ranks lowest.

In Albania, green energy is more developed than in other countries under consideration and accounts for almost a quarter of the national energy consumption. The alternative energy sector is least developed in the Republic of Moldova $(0.8 \%$ of national energy consumption). In terms of environmental indicators ( $\mathrm{CO}_{2}$ emissions), Albania demonstrates the lowest level $\left(1.8 \mathrm{t} \mathrm{CO}_{2} /\right.$ toe), with Bosnia and Herzegovina ranking highest ( $3.3 \mathrm{t} \mathrm{CO}_{2} /$ toe) due to the fact that thermal power stations that operate there rely mainly on lignite.

In general, the economic indicators and the characteristics of the energy sector are comparable across the countries under study. However, the Republic of Moldova ranks lowest in terms of its place in the ranking, production and consumption, exports, and energy affordability.

An analysis and systematization of factors influencing the energy security of the Republic of Moldova and their impact revealed the following [48]:

- growing dependence on the import of energy resources, in particular natural gas, whose share exceeds $50 \%$;

- insufficient power generation capacities covering only $30 \%$ of the total demand. The share of national electricity generation is constantly decreasing and is currently estimated at $25 \%$, which does not meet energy security requirements;

- when electricity is imported, the power lines operate in the limit overload mode;

- low operating reserve and insufficient transmission capacity of internal and external high-voltage tie lines. Under the current energy balance, any internal or external disturbances cause emergencies and power failures in the Republic of Moldova;

- large electricity and heat losses;

- highly worn-out power equipment, buildings, and structures (with an average wearand-tear value ranging from $60 \%$ to $70 \%$ ).

Moreover, there is not enough funding allocated for upgrading and modernizing the energy sector. In terms of capital investments, the energy industry lags behind many other sectors. Furthermore, electricity prices are raised in an uncoordinated fashion, with other management issues also playing their role [48].

The renewable energy potential in the Republic of Moldova is based on its favorable geographical position. A study by the International Renewable Energy Agency (IRENA) showed that the Republic of Moldova has a vast potential for the development of renewable energy, which is estimated at more than 21 GW [60]. This value is 10 times higher than the total installed capacity of all power stations in the country. The implementation of renewable energy projects does not cause environmental damage. The largest eco-friendly 
projects are the Moldova Energy and Biomass Project, and EU4Energy, which are funded by the European Union and bring positive results.

The methodology for assessing and choosing an alternative for the development of the energy sector of the Republic of Moldova was tested using data from a World Bank report that was funded by ESMAP (Energy Sector Management Assistance Program) and consists of a feasibility study and three main scenarios for the development of the energy sector in Moldova [49,55]:

(1) self-sufficiency scenario, which implies the availability of facilities that will be sufficient to meet the country's demand for energy; two alternatives (SS-1, SS-2).

(2) synchronous interconnection scenario, which implies that the energy sector will be disconnected from Ukraine and the Moldavskaya GRES (except for the S-3 alternative) and simultaneously connected to the European Network of Transmission System Operators (ENTSO-E); four alternatives (S-1, S-2, S-3, S-4).

(3) asynchronous interconnection scenario, which implies that the energy sector will be connected to the ENTSO-E system through Back-to-Back (BtB) stations while preserving links with Ukraine and the Moldavskaya GRES; two alternatives (A-1, A-2).

In this study, a scenario is understood as a combination of conditions for the development of the energy sector of the Republic of Moldova that can take the form of several alternatives. This combination includes the way of interaction with the energy sectors of the neighboring countries, and the fulfillment of engineering, legal, and other obligations in the energy sector for electricity interconnection within the European energy system. Alternatives are understood as different options of how to manage the functioning of the energy sector of the Republic of Moldova that are characterized by different features and parameters.

In the self-sufficiency scenario, facilities must be built in Moldova that will enable the country to meet its demand for energy. Two alternatives are being considered that are based on two types of fuel: natural gas and coal. The first alternative (SS-1) implies the use of both types of fuel, which will result in the diversification of fuels being imported and competition between the two types. The second alternative (SS-2) implies that only natural gas will be used, which can lead to a decrease in the country's energy security and dependence on one supplier (Gazprom).

The current investment value of each alternative exceeds USD 1 billion, with the biggest share allocated for the construction of new energy facilities. Investments in transport networks account for $2.5 \%$ of the total amount of investments in new sources of energy generation [54]. The Republic of Moldova does not attract many investors; the share of direct investment in the country's GDP ranges from $1 \%$ to $2 \%$, which means that large-scale projects are possible to implement only if there are government guarantees or in the form of a PPP agreement. The self-sufficiency scenario will negatively affect the country's energy security due to the fact that the dependence on imported fuel will increase.

The synchronous interconnection scenario implies competition between types of fuel and the opportunity to purchase significant amounts of electricity at competitive prices. The implementation of such a scenario requires that technical problems should be solved in order to connect to the ENTSO-E system, which can take 10 to 15 years. In addition, all the alternatives within this scenario (with the exception of S-3) have a significant drawback that consists in the fact that the energy system of the Republic of Moldova will be disconnected from the Moldavskaya GRES and Ukraine. This will deprive Moldova of the benefits that the competition between East and West in the energy sector brings.

The asynchronous interconnection scenario has several advantages:

(1) Diversification of electricity and fuel sources due to the fact that the electricity purchased at competitive prices from Romania is produced using various types of fuel (coal, natural gas, nuclear energy, and renewable energy sources). Also, Moldova will continue to have the opportunity to purchase electricity from the Moldavskaya GRES and Ukraine. 
(2) Competition in the energy market. There is no need to disconnect from the Moldavskaya GRES and Ukraine. Being connected in the asynchronous mode will allow Moldova to continue to use the ancillary services provided by Ukraine and the Moldavskaya GRES.

(3) A shorter implementation period compared to the synchronous options [48].

The main disadvantages of the asynchronous connection scenario include:

(1) higher costs compared to the synchronous interconnection scenario (however, they are not as high as in the self-sufficiency scenario);

(2) Moldova will have an observer status in the ENTSO-E system but will not be able to become a full-fledged member due to the fact that its energy system will remain part of the IPS/UPS system (the system of synchronous power transmission in the CIS countries).

The initial data on the alternatives for carrying out MCDA are presented in Figure 2.

\begin{tabular}{|c|c|c|c|c|c|c|c|}
\hline Варианты & $\begin{array}{l}\text { Current investment } \\
\text { value for a } 20 \text {-year } \\
\text { period }\end{array}$ & $\begin{array}{l}\text { Normalized } \\
\text { price for a } \\
\text { 20-year period }\end{array}$ & $\begin{array}{l}\text { Energy } \\
\text { security }\end{array}$ & Competition & $\begin{array}{l}\text { An opportunity for East-West } \\
\text { (and West-East) power } \\
\text { transmission }\end{array}$ & $\begin{array}{l}\text { Environmental } \\
\text { impact }\end{array}$ & $\begin{array}{l}\text { Operational } \\
\text { issues }\end{array}$ \\
\hline SS-1 & 1023 & 16,6 & 0,718 & 0 & 220 & 30,6 & 0 \\
\hline S-1 & 285 & 15,01 & 0,364 & 1 & 0 & 29,2 & 23 \\
\hline S-2 & 266 & 14,96 & 0,364 & 1 & 0 & 29,2 & 23 \\
\hline$S-4$ & 322 & 15,07 & 0,364 & 1 & 0 & 29,2 & 23 \\
\hline A-1 & 529 & 15,58 & 0,713 & 3 & 1250 & 27,8 & 0 \\
\hline$A-2$ & 511 & 15,46 & 0.713 & 3 & 1250 & 27,8 & 0 \\
\hline
\end{tabular}

Figure 2. Initial data for choosing a growth alternative for the energy sector of the Republic of Moldova. Source: Developed by the authors. * The first column of the table shows the eight alternatives.

Figure 3 shows how scores were calculated for the alternatives using the software product.

\begin{tabular}{|c|c|c|c|c|c|c|c|}
\hline Варианты & $\begin{array}{l}\text { Current investment } \\
\text { value for a } 20 \text { year } \\
\text { period }\end{array}$ & $\begin{array}{l}\text { Normalized } \\
\text { price for a } \\
20 \text {-year period }\end{array}$ & $\begin{array}{l}\text { Energy } \\
\text { security }\end{array}$ & Competition & $\begin{array}{l}\text { An opportunity for East-West } \\
\text { (and West-East) power } \\
\text { transmission }\end{array}$ & $\begin{array}{l}\text { Environmental } \\
\text { impact }\end{array}$ & $\begin{array}{l}\text { Operational } \\
\text { issues }\end{array}$ \\
\hline SS-1 & 0 & 0 & 100 & 0 & 18 & 0 & 100 \\
\hline SS-2 & 41 & 17 & 86 & 0 & 18 & 100 & 100 \\
\hline S-1 & 94 & 96 & 0 & 33 & 0 & 12 & 0 \\
\hline$S-2$ & 97 & 99 & 0 & 33 & 0 & 12 & 0 \\
\hline$S-4$ & 90 & 92 & 0 & 33 & 0 & 12 & 0 \\
\hline A-1 & 63 & 61 & 99 & 100 & 100 & 23 & 100 \\
\hline$A-2$ & 66 & 69 & 99 & 100 & 100 & 23 & 100 \\
\hline Weighting Factor & 0,2 & 0,2 & 0,2 & 0,2 & 0,05 & 0,1 & 0,05 \\
\hline
\end{tabular}

Figure 3. Scoring the indicators and calculating their weighing factors using a computer program. Source: Developed by the authors.

The last row in the Figure 3 contains the values of the weighting factor ranging from 0 to 1 . For the energy sector of the Republic of Moldova, the most significant indicators are those that characterize the state of the economy and society. Among them are such economic indicators as the current investment value for a 20-year period and the degree of energy security and such social indicators as the normalized price for a 20-year period and the level of competition. These indicators are assigned values of 0.2 . The choice of these indicators in particular is explained by the critical condition of the energy sector, lack of investment, and the need to ensure energy equity for consumers. The environmental 
indicator (impact on the environment) is less significant for the conditions of the Republic of Moldova because coal is not used as the source of energy at thermal power plants (except for the SS-1 alternative). This is why it was assigned a value of 0.1 . The other two indicators (an opportunity for East-West (and West-East) power transmission and operational issues) lie within the sphere of public administration. The Government of the Republic of Moldova has been successfully improving the regulatory framework and fostering international interactions. Therefore, these indicators were assigned values of 0.05 .

The procedure for scoring and ranking is shown in Figure 4.

\begin{tabular}{|c|c|c|c|c|c|c|c|c|c|}
\hline Варианты & $\begin{array}{l}\text { Current } \\
\text { investment value } \\
\text { for a } 20 \text { year } \\
\text { period }\end{array}$ & $\begin{array}{l}\text { Normalized price } \\
\text { for a } 20 \text {-year } \\
\text { period }\end{array}$ & Energy security & Competition & $\begin{array}{l}\text { An opportunity for } \\
\text { East-West (and } \\
\text { West-East) power } \\
\text { transmission }\end{array}$ & $\begin{array}{l}\text { Environmental } \\
\text { impact }\end{array}$ & Operational issues & Общий балл & Рейтинг \\
\hline$A-2$ & 13,2 & 13,8 & 19,8 & 20 & 5 & 2,3 & 5 & 79,1 & 1 \\
\hline A-1 & 12.6 & 12,2 & 19.8 & 20 & 5 & 2,3 & 5 & 76.9 & 2 \\
\hline s-3 & 20 & 20 & 13,4 & 134 & 24 & 4.1 & 1.75 & 75.05 & 3 \\
\hline S-2 & 19,4 & 19,8 & 0 & 6,6 & 0 & 1,2 & 0 & 47 & 4 \\
\hline S-1 & 18,8 & 19,2 & 0 & 6.6 & 0 & 1,2 & 0 & 45,8 & 5 \\
\hline SS-2 & 8,2 & 3,4 & 17,2 & 0 & 0,9 & 10 & 5 & 44,7 & 6 \\
\hline S-4 & 18 & 18,4 & 0 & 6,6 & 0 & 1,2 & 0 & 44,2 & 7 \\
\hline SS-1 & 0 & 0 & 20 & 0 & 0,9 & 0 & 5 & 25,9 & 8 \\
\hline
\end{tabular}

Figure 4. Ranking the alternatives using a computer program. Source: Developed by the authors.

As a result of MCDA, alternative A-2 (the asynchronous interconnection scenario) was selected, which ranked highest taking into account the indicators and the weighting factors. The procedure for choosing the best alternative for the energy sector of the Republic of Moldova was supplemented by an analysis of the sensitivity of the best alternative that was also carried out using the software. At the final step of MCDA (Table 2), the sensitivity analysis indicators were obtained: relative change in the score of the alternative caused by changes in the indicators within a selected range, and the elasticity of change in the score of an alternative. The software allows the user to select indicators and ranges of their changes to conduct a sensitivity analysis. Indicators that are characterized by a high probability of changes in the forecast period (20 years) and high risks were selected.

Table 2. Sensitivity analysis using a computer program.

\begin{tabular}{ccc}
\hline Characteristics & $\begin{array}{c}\text { Current Investment Value } \\
\text { for a 20-Year Period }\end{array}$ & $\begin{array}{c}\text { Normalized Price for a } \\
\text { 20-Year Period }\end{array}$ \\
\hline Initial value of the indicator & 511 & 15.46 \\
Initial total value (point) & 79.1 & 79.1 \\
1st \% change & $+20 \%$ & $+7 \%$ \\
New total value 1 & 76.3 & 65.9 \\
\% change in total value & $3.54 \%$ & $16.69 \%$ \\
Sensitivity indicator & 0.18 & 2.38 \\
2nd \% change & $-10 \%$ & $-15 \%$ \\
New total value 2 & 80.3 & 85.3 \\
\% change in total value 2 & $1.52 \%$ & $7.84 \%$ \\
Sensitivity indicator 2 & 0.15 & 0.52 \\
3d\% change & $+25 \%$ & $+25 \%$ \\
New total value 3 & 75.7 & 65.3 \\
$\%$ change in total value 3 & $4.3 \%$ & $17.45 \%$ \\
Sensitivity indicator 3 & 0.17 & 0.70 \\
4th $\%$ change & $-5 \%$ & $-5 \%$ \\
New total value 4 & 79.7 & 85.3 \\
\% change in total value 4 & $0.76 \%$ & $7.84 \%$ \\
Sensitivity indicator 4 & 0.15 & 1.57 \\
\hline
\end{tabular}

Source: Developed by the authors. 
The results presented in Table 2 make it possible to conclude that the A-2 alternative that was selected is more dependent on changes in the normalized price for a 20-year period than on the current investment value for a 20-year period, which is reflected by a greater sensitivity value and a change in the final score.

Based on MCDA, the advantages of the asynchronous interconnection scenario for the development of the energy sector were identified, which implies both partial integration with the ENTSO-E system and cooperation with Ukraine and Transnistria.

\section{Discussion}

The implementation of the A-2 alternative will contribute to the sustainable development of the energy sector in the Republic of Moldova as it complies with the principles of sustainable development and the energy trilemma concept. Four principles of sustainable functioning are proposed for the energy systems of countries with transition economies:

- the principle of diversification of energy resources and energy generation sources is based on the constant development of the energy sector that is fostered by various energy resources and energy generation methods, which will reduce energy dependence and positively influence the energy security of the country. Diversification of energy resources and energy generation sources can be performed if a country holds different kinds of energy resources (natural gas, petroleum products, and coal) and is able to generate electricity and heat in various ways. In 2017, according to the National Bureau of Statistics (NBS), the energy demand in the Republic of Moldova was secured by its own energy resources by only $26.2 \%$, with the rest of the energy being imported. The country has the opportunity to diversify its energy generation sources due to the potential for green energy production.

- the principle of ensuring energy efficiency is aimed at reducing the consumption of energy resources (or natural capital) and increasing the efficiency of how the reproduced capital functions (in order to create value added). Better energy efficiency is of particular importance for countries with transition economies, most of which are characterized by low or middle income. The Republic of Moldova belongs to the group of countries with income per capita below the average.

- the principle of ensuring energy affordability, which is associated with population growth in a number of developing countries, a decrease in energy production and consumption, and a decrease in purchasing power. In terms of kWh per average salary, the Republic of Moldova ranked lowest of all European countries in 2019.

- the principle of green energy production, which is necessary to reduce the anthropogenic impact of the sector on the environment. Green energy production is a tool for ensuring environmental safety that minimizes environmental risks and negative impact on the environment in the production of electricity and heat. In the Republic of Moldova, $\mathrm{CO}_{2}$ emissions have been demonstrating an upward trend since 2000 .

These principles serve as guidelines for energy policy developers. Therefore, the alternatives for the development of the energy sector of the Republic of Moldova must correspond to these principles.

Energy security will be ensured through energy resource diversification. Through interaction with the European energy system (ENTSO-E), the Ukrainian energy system, and the Moldavskaya GRES, the level of competition is maximized (3, Figure 2). This will make energy supply more reliable and make the energy sources used over the forecast period more diverse.

Energy equity is achieved through price cuts associated with competition. In the A-2 alternative, the price depends on several electricity suppliers (i.e., on competition). Energy price optimization helps to restore the country's economy and improve social well-being.

Environmental sustainability can be achieved by using renewable energy sources, as the European Union's development is focused on using green energy. The inclusion of renewable energy sources in domestic energy generation increases the degree of energy 
security $\left(0.713\right.$, Figure 2). The development of green energy will also help to reduce $\mathrm{CO}_{2}$ emissions (27.8 million tons over 20 years, Figure 2).

To implement the A-2 alternative, investments of $\$ 511$ million are required to meet the future demand for electricity in Moldova and to ensure sustainable international interactions. Within this alternative, transit capacity (1250 MW) is the biggest among the other options under consideration (Figure 2).

The period of implementing the A-2 alternative is not associated with any operational issues (0, Figure 2).

The A-2 alternative that was chosen as a result of the analysis discussed here is the most attractive and realistic in the current conditions of the Republic of Moldova. In a country that does not have domestic energy resources, being self-sufficient in terms of energy generation seems less realistic than cooperating with other countries. Increasing domestic generation, tapping into the potential of green energy, connecting to the international energy system, and creating a competitive energy market will enable the energy sector of the Republic of Moldova to overcome the crisis and ensure its sustainable development.

\section{Conclusions and Implications}

The European countries with transition economies that were analyzed (Appendix A) have insufficient fuel and energy resources, import oil and gas, and do not use nuclear energy. They have the potential to produce renewable energy but it is very rarely used. The development of renewable energy technologies and facilities requires a lot of investments, an option which is currently inaccessible for these countries.

There is sufficient energy security in the countries under consideration (Appendix A) except for Albania and the Republic of Moldova. Energy equality is at a good level in all of them except for the Republic of Moldova. Environmental sustainability is at a sufficient level in all of them except for the Republic of Moldova.

Local (national) circumstances in all of the countries being considered (Appendix A) are not very favorable, which indicates problems in the macroeconomic environment and public administration and means that it is necessary to develop new regulations in the energy sector. The unfavorable economic situation in these countries results in low energy availability in spite of relatively low prices. To improve the efficiency of their energy sectors, all the countries on the list are focused on the development of domestic energy generation, energy integration into Europe, the development of renewable energy facilities, the environmental sustainability of the energy sector, and the provision of energy equality.

A comparative analysis of countries with economies in transition based on their economic and energy indicators showed that the Republic of Moldova ranks lowest in terms of the efficiency of its energy sector. It has the lowest energy efficiency index among European countries with economies in transition. This is explained by the current crisis in the energy sector.

The development of the energy sector as a fundamental infrastructure sector of the economy should be rationalized taking into account many social and economic effects within the framework of the concept of sustainable development.

The choice of a development path for the energy sector is based on the principles of sustainable development: diversification of energy resources and energy generation sources, ensuring energy efficiency, ensuring energy affordability, and green energy production.

Taking into account the factors that were identified, a set of principles that were suggested, and the ideas within the energy trilemma concept, the following indicators were selected to analyze the alternatives: (1) current investment value; (2) normalized price for electricity; (3) energy security; (4) level of competition; (5) an opportunity for power transmission between countries; (6) environmental impact; (7) operational issues.

Among the proposed indicators, an opportunity for power transmission between countries (5) and operational issues (7) take into account the situation with government regulation in the energy sector and strategic plans for its development. This can be important for countries planning to participate in energy integration programs. For countries that are 
more focused on being self-sufficient in terms of energy production, these indicators can be replaced by others or not used.

The values of the weighting factors are also determined depending on the importance of the factors for the energy sector of a particular country. The selected weights were assumed to be equal (with the exception of those for an opportunity for power transmission between countries (5) and operational issues (7), since integration issues in the Republic of Moldova are supported by the government and do not need to be given priority. In this country, the environmental impact indicator is also quite good.

In order to choose one out of eight alternatives for the energy sector of the Republic of Moldova, an economic and mathematical model based on multiple-criteria decision analysis (MCDA) and a software product were developed, using which the best alternative was selected.

When using MCDA to select an alternative for the development of the energy sector, it is recommended that the current state of the country's energy sector should be taken into account and the fundamental problems in the energy sector should be revealed along with the factors of sustainable development, on the basis of which the choice of MCDA indicators should be made.

The software product that was developed for conducting MCDA requires a large number of input data. This data is based on information that can be found in national and international reports. Unfortunately, there is only limited information in open access sources, and this information may not be relevant for the period of time being analyzed.

The proposed methodology is applicable to solving strategic problems connected with energy sector management. It encompasses such elements as sustainable development principles, problem analysis, the development of principles for managing the energy sector, and MCDA. The results that it produces allow for making an informed choice.

In the future, it is planned to improve the graphical presentations of the results of sensitivity analysis in the software for better data visualization.

Author Contributions: Conceptualization, T.P.; methodology, E.R. and T.P.; software, E.R.; validation, E.R.; formal analysis, E.R.; investigation, E.R.; data curation, E.R.; writing — original draft preparation, E.R.; writing-review and editing, T.P.; visualization, E.R.; supervision, T.P.; project administration, E.R and T.P. All authors have read and agreed to the published version of the manuscript.

Funding: This research received no external funding.

Institutional Review Board Statement: Not applicable.

Informed Consent Statement: Not applicable.

Data Availability Statement: In this section, please provide details regarding where data supporting reported results can be found, including links to publicly archived datasets analyzed or generated during the study.

Conflicts of Interest: The authors declare no conflict of interest.

\section{Abbreviations}

Table of nomenclature and acronyms.

$\begin{array}{ll}\text { MCDA } & \text { multiple-criteria decision analysis } \\ \text { SD } & \text { sustainable development } \\ \text { CIS countries } & \text { commonwealth of Independent States } \\ \text { EU } & \text { European Union } \\ \text { USSR } & \text { the Union of Soviet Socialist Republics } \\ \text { IRENA } & \text { Renewable Energy Agency } \\ \text { GW } & \text { Gigawatt } \\ \text { MWh } & \text { Megawatt } \\ \text { kWh } & \text { Kilowatt } \\ \text { BTU } & \text { British thermal unit } \\ \text { ESMAP } & \text { Energy Sector Management Assistance Program }\end{array}$




$\begin{array}{ll}\text { SS-1, SS-2 } & \text { self-sufficiency scenario } \\ \text { S-3 } & \text { synchronous interconnection scenario } \\ \text { A-1 } & \text { asynchronous interconnection scenario } \\ \text { BtB stations } & \text { Back-to-Back stations } \\ \text { ENTSO-E } & \text { European Network of Transmission System Operators } \\ \text { PPP agreement } & \text { public-private partnership } \\ \text { Moldavskaya GRES } & \text { Moldavian State District Power Plant } \\ \text { IPS/UPS system } & \text { the Integrated Power System/Unified Power System of Russia } \\ \text { NBS } & \text { National Bureau of Statistics } \\ \text { AAA to DDD } & \text { The country's AAA rating on the energy Sustainability index } \\ & \text { characterizes a country with a stable economy and high-quality energy } \\ & \text { policy. Country rating DDD-describes a country with an unstable } \\ & \text { economy and energy policy. }\end{array}$

\section{Appendix A}

Table A1. Energy sectors of European countries with transition economies: a comparative analysis.

\begin{tabular}{|c|c|c|c|c|c|c|}
\hline & Albania & $\begin{array}{l}\text { North } \\
\text { Macedonia }\end{array}$ & $\begin{array}{l}\text { Bosnia and } \\
\text { Herzegovina }\end{array}$ & Serbia & Montenegro & $\begin{array}{l}\text { The Republic } \\
\text { of Moldova }\end{array}$ \\
\hline Population, million people (2018) & 2.866 & 2.083 & 3.324 & 6.982 & 0.622 & 3.546 \\
\hline Area, sq. km & 27.400 & 25.220 & 51.200 & 87.460 & 13.450 & 32.890 \\
\hline GDP per capita, USD, 2018 & 5269 & 6084 & 6066 & 7247 & 8844 & 3227 \\
\hline World Energy Trilemma Index (place in the & 73 & 71 & 79 & 70 & 64 & 107 \\
\hline global ranking), 2019 & DBAc & $\mathrm{CBCc}$ & $\mathrm{BBCc}$ & $\mathrm{BBCc}$ & $\mathrm{CBBC}$ & DCDC \\
\hline $\begin{array}{c}\text { Electricity consumption per capita (MWh } \\
\text { per person), } 2017\end{array}$ & 2.2 & 3.2 & 3.8 & 4.7 & 5.0 & 1.6 \\
\hline $\begin{array}{l}\text { Primary energy production, quadrillion } \\
\text { BTU, } 2017\end{array}$ & 0.08 & 0.04 & 0.14 & 0.46 & 0.02 & 0.00 \\
\hline $\begin{array}{c}\text { Primary energy consumption, quadrillion } \\
\text { BTU, } 2017\end{array}$ & 0.11 & 0.1 & 0.25 & 0.64 & 0.04 & 0.13 \\
\hline $\begin{array}{l}\text { Primary energy intensity, MJ per dollar of } \\
\text { GDP, } 2015\end{array}$ & 2.89 & 4.23 & 8.72 & 6.56 & 4.45 & 8.39 \\
\hline Net electricity generation, billion $\mathrm{kWh}$ & $\begin{array}{c}4.48 \\
(2017)\end{array}$ & $5.33(2017)$ & 15.69 (2017) & $\begin{array}{l}35.54 \\
(2018)\end{array}$ & 3.68 (2018) & 4.68 (2017) \\
\hline $\begin{array}{l}\text { Net nuclear power generation, billion } \mathrm{kWh} \text {, } \\
\qquad 2017\end{array}$ & 0.00 & 0.00 & 0.00 & 0.00 & 0.00 & 0.00 \\
\hline $\begin{array}{l}\text { Net hydropower generation, billion kWh, } \\
\qquad 2017\end{array}$ & 4.48 & 1.1 & 3.95 & 9.06 & 1.01 & 0.28 \\
\hline $\begin{array}{c}\text { Net geothermal power generation, } \\
\text { billion } \mathrm{kWh}, 2017\end{array}$ & 0.00 & 0.00 & 0.00 & 0.00 & 0.00 & 0.00 \\
\hline $\begin{array}{l}\text { Net wind power generation, billion kWh, } \\
\qquad 2017\end{array}$ & 0.00 & 0.11 & 0.00 & 0.05 & 0.10 & 0.01 \\
\hline $\begin{array}{l}\text { Net biomass energy production and } \\
\text { waste-to-energy production, billion } \mathrm{kWh} \text {, }\end{array}$ & 0.00 & 0.05 & 0.04 & 0.08 & 0.00 & 0.02 \\
\hline $\begin{array}{l}\text { Net electricity consumption, billion kWh, } \\
2017\end{array}$ & 5.03 & 6.31 & 12.50 & 30.41 & 3.00 & 5.24 \\
\hline Electricity exports, billion kWh, 2017 & 0.49 & 0.31 & 5.19 & 5.72 & 0.42 & 0.00 \\
\hline Electricity imports, billion kWh, 2017 & 2.92 & 2.29 & 3.35 & 6.55 & 1.54 & 1.13 \\
\hline $\begin{array}{l}\text { The share of fossil fuels in total energy } \\
\text { consumption, } \%, 2014\end{array}$ & 61.4 & 79.4 & 77.5 & 83.9 & 64.7 & 88.7 \\
\hline $\begin{array}{c}\text { The share of alternative sources of energy } \\
\text { and nuclear power in total energy } \\
\text { consumption, } \%\end{array}$ & $\begin{array}{c}24.5 \\
(2014)\end{array}$ & $19.9(2015)$ & $4.3(2014)$ & $5.7(2014)$ & $13.0(2014)$ & $0.8(2014)$ \\
\hline $\begin{array}{c}\mathrm{CO}_{2} \text { intensity of the energy mix } \\
\left(\mathrm{t} \mathrm{CO}_{2} / \text { toe }\right)\end{array}$ & $1.8(2017)$ & $2.7(2017)$ & $3.3(2017)$ & $3.0(2017)$ & $2.2(2017)$ & $2.0(2018)$ \\
\hline $\begin{array}{l}\text { Household electricity price per } 1 \mathrm{kWh} \text {, in } \\
\text { EUR (according to Eurostat), } 2018\end{array}$ & 0.09 & 0.078 & 0.087 & 0.07 & 0.1 & 0.09 \\
\hline $\begin{array}{l}\text { Electricity affordability for individuals (the } \\
\text { amount of electricity per average salary), } \\
\text { kWh, } 2019\end{array}$ & 3861 & 5018 & 5293 & 5926 & 4961 & 3069 \\
\hline
\end{tabular}




\section{References}

1. Litvinenko, V.S.; Tsvetkov, P.S.; Dvoynikov, M.V.; Buslayev, G.V. Baryery realizatsii vodorodnykh initsiativ v kontekste ustoychivogo razvitiya globalnoy energetiki. Zapiski Gornogo Instituta 2020, 244, 421-431.

2. Yurak, V.V.; Dushin, A.V.; Mochalova, L.A. Protiv ustoychivogo razvitiya: Stsenarii budushchego. Zapiski Gornogo Instituta 2020, 242, 242-247.

3. Knysh, V.A.; Ivanova, L.V. Cirkulyarnaya ekonomika: Ugroza dlya predpriyatij gornodobyvayushchego sektora ili drajver ih tekhnologicheskogo razvitiya? Gornyj Zhurnal 2020, 9, 33-41. [CrossRef]

4. Greene, D.L. Measuring Energy Sustainability; MIT Press: Cambridge, MA, USA, 2009; pp. 354-373.

5. Apolonskiy, O.Y. Globalnyye problemy ustoychivogo energeticheskogo razvitiya i mirovoy opyt ikh resheniya. Energeticheskaya Politika 2010, 4-5, 80-92.

6. Zorina, T.G. Ustoychivoye razvitiye energetiki: Sushchnost i metodicheskiye podkhody k otsenke. Sovremennyye Tekhnologii Upravleniya 2015, 1, 4905.

7. Chegis, R.; Pusinayte, R. Otritsatelnyye vneshniye effekty i ustoychivoye razvitiye v sfere energetiki. Baltiyskiy Region 2010, 1, 108-118.

8. United Nations World Commission on Environment and Development. Report of the World Commission on Environment and Development: Our Common Future; Oxford University Press: Oxford, UK, 1987.

9. Cîrstea, S.D.; Moldovan-Teselios, C.; Cîrstea, A.; Turcu, A.C.; Darab, C.P. Evaluating renewable energy sustainability by composite index. Sustainability 2018, 10, 811. [CrossRef]

10. World Energy Trilemma Index. World Energy Council in Partnership with Oliver Wyman. Available online: https://www worldenergy.org/publications/entry/world-energy-trilemma-index-2019 (accessed on 30 March 2020).

11. Kaplunov, D.R.; Rylnikova, M.V.; Radchenko, D.N. Usloviya ustoychivogo razvitiya mineralno-syryevogo kompleksa Rossii. Gornyy Inf. Anal. Byulleten Nauchno-Tekhnicheskiy Zhurnal 2014, 6, 3-11.

12. Pronin, E.M.; Vasilyev, V.E.; Tsvetkov, V.Y. Faktory, opredelyayushchiye ustoychivoye razvitiye predpriyatiy mineralno-syryevogo kompleksa, i ikh vliyaniye na otsenku rezultatov deyatelnosti predpriyatiy. Zap. Gorn. Inst. 2011, 191, $176-182$.

13. Brodny, J.; Tutak, M. Analyzing similarities between the european union countries in terms of the structure and volume of energy production from renewable energy sources. Energies 2020, 13, 913. [CrossRef]

14. Tutak, M.; Brodny, J.; Siwiec, D.; Ulewicz, R.; Bindzár, P. Studying the level of sustainable energy development of the European Union countries and their similarity based on the economic and demographic potential. Energies 2020, 13, 6643. [CrossRef]

15. World Energy Council. London. Available online: https:/ / www.worldenergy.org/ (accessed on 30 March 2020).

16. United Nations Conference on Environment and Development-UNCED. Agenda 21. Available online: http://www.un.org/ esa/dsd/agenda21/ (accessed on 2 September 2020).

17. Steger, U.; Achterberg, W.; Blok, K.; Bode, H.; Frenz, W.; Gather, C.; Hanekamp, G.; Imboden, D.; Jahnke, M.; Kost, M.; et al. Sustainable Development and Innovation in the Energy Sector; Springer: Berlin/Heidelberg, Germany, 2003.

18. Pashke, M. Pravovyye aspekty novoy energeticheskoy politiki Germanii. Zapiski Gornogo Instituta 2017, 226, 487-496.

19. Catrini, A.P.; Piacentino, A.; Markovska, N.; Guzović, Z.; Vad Mathiesen, B.; Ferrari, S.; Duić, N.; Lund, H. Sustainable development of energy, water and environment systems. Energy 2020, 190, 116432.

20. Cioca, L.-I.; Ivascu, L.; Rada, E.C.; Torretta, V.; Ionescu, G. Sustainable development and technological impact on $\mathrm{CO}_{2}$ reducing conditions in Romania. Sustainability 2015, 7, 1637-1650. [CrossRef]

21. Ulanov, V.L.; Ulanova, E.Y. Vliyaniye vneshnikh faktorov na natsionalnuyu energeticheskuyu bezopasnost. Zapiski Gornogo Instituta 2019, 238, 474-480.

22. Bykova, E.V. Metodologiya analiza energeticheskoy bezopasnosti. Covremennaya Nauka Issled. Idei Rezult. Tekhnologii 2013, 2, 138-144.

23. Bykova, E.V. Kratkosrochnyye prognozy toplivno-energeticheskikh balansov pri analize energeticheskoy bezopasnosti. Covremennaya Nauka Issled. Idei Rezult. Tekhnologii 2016, 1, 124-129.

24. Bykova, E.V. Investicii kak instrument obespecheniya energeticheskoj bezopasnosti Moldovy. Ekonomiks $2013,3,47-61$.

25. Bykova, E.V.; Grodetskiy, M.V. Analiz i monitoring energeticheskoy bezopasnosti i prognozirovaniye znacheniy indikatorov metodom uslovnogo nelineynogo matematicheskogo programmirovaniya. Ekonomika Regiona 2011, 3, $234-240$.

26. Duka, G.G.; Postolatiy, V.M.; Bykova, E.V. Aspekty problemy energeticheskoy bezopasnosti Respubliki Moldova. Probl. Energeticii Reg. 2005, 1, 15.

27. Cherepovitsyn, A.E.; Ilinova, A.A.; Smirnova, N.V. Ekonomicheskiye stimuly dlya energoeffektivnogo razvitiya i snizheniya emissii uglekislogo gaza: Opyt Avstralii. Ross. Ekon. Internet Zhurnal 2013, 4, 1-4. Available online: http://www.e-rej.ru/ publications /151/?PAGEN_1=3 (accessed on 25 March 2020).

28. Porfiryev, B.N. Alternativnaya energetika kak faktor modernizatsii ekonomiki v usloviyakh VTO. Kontury Glob. Transform. Politika Ekon. Pravo 2013, 6, 97-109.

29. Olabi, A.G. Developments in sustainable energy and environmental protection. Energy 2012, 39, 2-5. [CrossRef]

30. Chu, C.-T.; Hawkes, A.D. A geographic information system-based global variable renewable potential assessment using spatially resolved simulation. Energy 2020, 193, 116630. [CrossRef]

31. Khoshnava, S.M.; Rostami, R.; Zin, R.M.; Kamyab, H.; Abd Majid, M.Z.; Yousefpour, A.; Mardani, A. Green efforts to link the economy and infrastructure strategies in the context of sustainable development. Energy 2020, 193, 116759. [CrossRef] 
32. Przychodzen, W.; Przychodzen, J. Determinants of renewable energy production in transition economies: A panel data approach. Energy 2020, 191, 116583. [CrossRef]

33. Büyüközkan, G.; Karabulut, Y.; Mukul, E. A novel renewable energy selection model for United Nations' sustainable development goals. Energy 2018, 165, 290-302. [CrossRef]

34. Global Innovations from the Energy Sector 2010-2020. World Economic Forum, May 2020. Available online: https://www. weforum.org/whitepapers/global-innovations-from-the-energy-sector (accessed on 20 September 2020).

35. Hoppe, T.; Butenko, A.; Heldeweg, M. Innovation in the European energy sector and regulatory responses to it: Guest editorial note. Sustainability 2018, 10, 416. [CrossRef]

36. Schulze, M.; Nehler, H.; Ottosson, M.; Thollander, P. Energy management in industry-A systematic review of previous findings and an integrative conceptual framework. J. Clean. Prod. 2015, 112, 3692-3708. [CrossRef]

37. Sa, A.; Thollander, P.; Rafiee, M. Industrial energy management systems and energy-related decision-making. Energies 2018, 11, 2784. [CrossRef]

38. Shilets, E.; Kravchenko, V.; Luk'yanenko, T. Energeticheskaya trilemma-Osnova ustojchivogo razvitiya toplivnoenergeticheskogo kompleksa. Vestn. Inst. Ekon. Issled. 2017, 3, 27-34.

39. Tomei, J.; Gent, D. Equity and the Energy Trilemma: Delivering Sustainable Energy Access in Low-Income Communities; International Institute for Environment and Development: London, UK, 2015; ISBN 978-1-78431-215-2.

40. Šprajc, P.; Bjegović, M.; Vasić, B. Energy security in decision making and governance-Methodological analysis of energy trilemma index. Renew. Sustain. Energy Rev. 2019, 114, 109341. [CrossRef]

41. Maier, H.R.; Guillaume, J.; Van Delden, H.; Riddell, G.; Haasnoot, M.; Kwakkel, J.H. An uncertain future, deep uncertainty, scenarios, robustness and adaptation: How do they fit together? Environ. Model. Softw. 2016, 81, 154-164. [CrossRef]

42. Soroudi, A.; Amraee, T. Decision making under uncertainty in energy systems: State of the art. Renew. Sustain. Energy Rev. 2013, 28, 376-384. [CrossRef]

43. Foley, A.M.; Ó Gallachóir, B.P.; Hur, J.; Baldick, R.; McKeogh, E.J. A strategic review of electricity systems models. Energy 2010, 35, 4522-4530. [CrossRef]

44. Ofitserov-Belsky, D. Problemy energeticheskoj bezopasnosti Respubliki Moldova. Ekon. Postsovetskih Stran 2020, 146-156. [CrossRef]

45. Postolatij, V.M. Nekotorye aspekty obrazovaniya edinogo rynka ES “Evrelektrik” i Moldovy sredi stran SNG. Probl. Reg. Energetiki 2006, 1, 30-36.

46. Postolatij, V.M.; Bykova, E.V.; Kiorsak, M.V. Sovremennye Problemy i Vozmozhnye napravleniya Dal'nejshego Razvitiya Elektroenergetiki Respubliki Moldova. Available online: http://www.ie.asm.md/assets/files/05-A01.pdf (accessed on 23 August 2020).

47. Comendant, I. Impactul economic si de securitate a interconectarii sistemelor electroenergetice ai Republicii Moldova si cel Vest European. Probl. Energeticii Reg. 2017, 2, 148-158.

48. Resniova, E.A.; Ponomarenko, T.V.; Moskera, A.P.U. Mnogokriterial'nyj analiz napravlenij strategicheskogo razvitiya energeticheskogo sektora. Internet-Zhurnal Vestnik Evrazijsk. Nauki 2020, 2, 1-12. Available online: https:// esj.today/PDF/82ECVN220.pdf (accessed on 7 June 2020).

49. Stewart, J. Strategic Energy Management (SEM) Evaluation Protocol. The Uniform Methods Project: Methods for Determining Energy Efficiency Savings for Specific Measures; National Renewable Energy Laboratoty, US Department of Energy, Office of Scientific and Technical Information: Oak Ridge, TN, USA, 2017.

50. Massel, A.; Bakhvalov, K. Primeneniye intellektualnykh tekhnologiy dlya resheniya problemy nauchnogo obosnovaniya strategicheskikh resheniy po tsifrovoy transformatsii energetiki. Inf. Mat. Tekhnologii Nauke Upr. 2019, 1, 47-60. [CrossRef]

51. Massel, L.; Kuzmin, V. Tools for strategic decision support in energy sector based on situation management and semantic modeling. In Proceedings of the 5th International Workshop Critical Infrastructures: Contingency Management, Intelligent, Agent-Based, Cloud Computing and Cyber Security (IWCI 2018), Baikalsk, Russia, 17-24 March 2018; pp. 129-135.

52. Wang, J.J.; Jing, Y.Y.; Zhang, C.F.; Zhao, J.H. Review on multi-criteria decision analysis aid in sustainable energy decision-making. Renew. Sustain. Energy Rev. 2009, 13, 2263-2278. [CrossRef]

53. Streimikiene, D.; Siksnelyte, I. Sustainability assessment of electricity market models in selected developed world countries. Renew. Sustain. Energy Rev. 2016, 57, 72-82. [CrossRef]

54. ESMAP. 2015 Annual Report. Moldova Electric Power Market Options Sector Study. Available online: https://www.esmap.org/ sites/default/files/esmap-files / 102512-AR-PUBLIC-Box394832B-ESMAP-ANNUAL-REPORT-2015.pdf (accessed on 17 May 2020).

55. Bykova, E.; Caranu, M.; Kirillova, T. Podhody k formirovaniyu sistemy ekologicheskih indikatorov kak sostavlyayushchej sistemy indikatorov energeticheskoj bezopasnosti. Probl. Reg. Energetiki 2006, 1, 49-58.

56. Svidetel'stvo o gosudarstvennoj registracii programmy dlya EVM 2020615938 Rossijskaya Federaciya. Programma po primeneniyu MKAR pri vybore napravleniya razvitiya energeticheskogo sektora Respubliki Moldova: № 2020614398; zayavl. 15.05.2020; opubl. 04.06.2020 Byul. № 6/Reshnyova, E.; Ponomarenko, T.V.// zayavitel’ Sankt-Peterburgskij gornyj universitet.

57. Worldbank. Available online: https://www.worldbank.org/ (accessed on 17 May 2020).

58. World Bank. The Little Green Data Book 2017. World Development Indicators 2017; World Bank: Washington, DC, USA, 2017; 240p. 
59. Eurostat-Data Explorer. Available online: https:/ /appsso.eurostat.ec.europa.eu/nui/show.do?dataset=nrg_pc_204\&lang=en (accessed on 19 May 2020).

60. International Renewable Energy Agency. Available online: http:/ / renewnews.ru/irena/ (accessed on 15 May 2020).

61. Mirovoy Atlas Dannykh. Available online: https:// knoema.ru (accessed on 15 May 2020).

62. Mirovaya Energeticheskaya Statistika. Available online: https://yearbook.enerdata.ru/ (accessed on 16 May 2020). 